Dhaka Univ. J. Biol. Sci. 27(1): 93-100, 2018 (January)

\title{
FUNGI ASSOCIATED WITH ANTHRACNOSE OF MANGO (MANGIFERA INDICA L.) FRUITS AND THEIR PATHOGENIC POTENTIALITY
}

\author{
FARHANA Islam, SHAmim Shamsi AND Md AbUl BashaR* \\ Department of Botany, University of Dhaka, Dhaka-1000, Bangladesh
}

Key words: Fungi, Anthracnose, Mangifera indica, Pathogenic potentiality

\begin{abstract}
A total of ten fungal species were isolated from the anthracnose symptoms of three varieties of Mangifera indica L. viz., Himsagar, Langra and Amrapali. The isolated fungi were Alternaria alternata (Fr.) Keissler, Aspergillus flavus Link, A. fumigatus Fresenius, A. niger van Tiegh., Colletotrichum gloeosporioides (Penz.) Sacc., Fusarium semitectum Berk. \& Rav., Papulaspora sp. Preuss., Penicillium sp. Link., Pestalotiopsis guepinii (Desm.) Stey. and Rhizopus stolonifer (Ehrenb.) Vull. Colletotrichum gloeosporioides showed the highest per cent (26.82) frequency in Himsagar whereas R. stolonifer showed the lowest (2.22). Pestalotiopsis guepinii showed the highest per cent (46.83) frequency in Langra whereas $R$. stolonifer showed the lowest (1.17). Colletotrichum gloeosporioides showed the highest per cent (38.67) frequency in Amrapali whereas Papulaspora sp. showed the lowest (4.00). Among the isolated fungi C. gloeosporioides, F. semitectum and P. guepinii were found to be pathogenic to three mango varieties. Association of Fusarium semitectum, Papulaspora sp. and Pestalotiopsis guepinii with mango is new record in Bangladesh.
\end{abstract}

\section{Introduction}

Mango (Mangifera indica L.) is the most popular and commonly eaten fruit among millions of people in tropical areas ${ }^{(1-2)}$ and it belongs to the family Anacardiaceae ${ }^{(3)}$. It is considered to be the king of fruits due to its wide ecological range, delicious taste, excellent flavor, very high nutritive and medicinal value as well as great religious historical significance ${ }^{(4)}$. Mango is the national tree of Bangladesh and national fruit of India, Pakistan and the Philippines(5). It is also an important commercial crop that currently ranks fifth among the major fruits cultivated worldwide(5). Bangladesh is one of the major mango producing countries and it ranks 8th among the top mango producing countries in the world( ${ }^{(6)}$. In Bangladesh in terms of total area and production of fruit crops, mango ranks first in area and third in production(7). There are a number of mango varieties in Bangladesh of which Langra, Bombai, Gopalbhog, Amrapali, Khirsapat, Himsagar, Mohanbhog and Ashwina are commercially important.

" $\overline{\text { Author for correspondence: } \triangleleft b o t a n y b a s h a r @ y a h o o . c o m>. ~}$ 
Mango suffers from several diseases at all stages of its life cycle and the post-harvest loss of mango is up to $17-36^{(8)}$. In Bangladesh 18 mango diseases have been reported ${ }^{(9)}$. The most common diseases of mangoes in Bangladesh are anthracnose, stem-end rot, powdery mildew, fruit rot, sooty mould and die back ${ }^{(10)}$. Himsagar, Langra and Amrapali varieties are most popular varieties in Bangladesh but they are frequently infected with fungi after harvest. Many researches has been done in home and abroad regarding nutrient values of mango but fungal diseases of these three varieties are inadequate ${ }^{(4,8,9)}$. Therefore, the present multidisciplinary research has been undertaken to identify the causal organism of the disease of three different mango varieties viz., Himsagor, Langra and Amrapali.

\section{Materials and Methods}

Three varieties of Mangifera indica L. viz., Himsagar, Langra and Amrapali were collected from five different markets of Dhaka city, namely Farmgate, Kollayanpur, Kawran bazaar, Mirpur-10 and Pirerbagh bazaar during the period of April to November 2016. Samples with anthracnose symptoms were collected in separate sterile polyethylene bags, labeled properly and then brought to the laboratory for isolation of fungi. The fungi associated with mango were isolated following "Tissue planting method" on PDA medium (11). The microscopic observations of the isolated fungi were recorded under a digital camera. Morphological structures of the fungi were drawn in detail with the help of camera lucida. Identifications of the isolates were determined following the standard literature ${ }^{(12-14)}$.

Pathogenicity test of the fungal isolates has been done following Akter and Shamsi with slight modification (15). Healthy mangoes were collected from the selected market and washed thoroughly in running tap water and dipped in one liter of $10 \%$ Chlorox solution for surface sterilization for three minutes. Then mangoes were washed three times in sterilized distilled water to remove Chlorox solution from the surface. Excess water from the surface of the mango was removed by pressing them between two sheets of previously sterilized filter paper. Suitable sized plastic boxes were sterilized with spirit. Sterilized cotton was placed in a corner of box to maintain humidity. Before spraying, the fruits were scratched with sterilized niddle. Then fruits were inoculated by spraying the conidial suspension $\left(10^{5}\right.$ conidia $\left./ \mathrm{ml}\right)$ of isolated fungi separately with an atomizer and placed into separate plastic boxes. In control set, sterilized distilled water was used instead of conidial suspension on the sterilized mango surface. The inoculated mango fruits with plastic boxes were incubated at $25 \pm 2^{\circ} \mathrm{C}$ for 7 days. Observation was made after 7 days, when the fruits had developed characteristic symptoms. The fungi were isolated from artificially inoculated fruits and compared with the previous one which showed the disease symptoms naturally infected fruits. 


\section{Results and Discussion}

A total of ten fungi were isolated from the infected fruits of three varieties of Mangifera indica. The isolated fungi were Alternaria alternata, Aspergillus flavus, A. fumigatus, A. niger, Colletotrichum gloeosporioides, Fusarium semitectum, Papulaspora sp., Penicillium sp., Pestalotiopsis guepinii and Rhizopus stolonifer (Table 1).

Table 1. Per cent frequency of fungi associated with diseased mango variety Himsagar.

\begin{tabular}{lcccccc}
\hline \multirow{2}{*}{$\begin{array}{l}\text { Name of } \\
\text { fungi }\end{array}$} & \multicolumn{5}{c}{ \% frequency of fungi from different markets (date of isolation) } \\
\cline { 2 - 7 } & Pirerbagh & Mirpur-10 & Kollaynpur & $\begin{array}{c}\text { Kawran } \\
\text { bazaar }\end{array}$ & Farmgate & Mean \\
\hline $\begin{array}{l}\text { Alternaria alternata } \\
\text { Aspergillus flavus }\end{array}$ & - & - & 16.67 & & & 3.33 \\
A. fumigatus & 3.33 & - & 5.56 & - & 13.33 & 4.44 \\
A. niger & 13.33 & - & 5.56 & 20.00 & - & 7.78 \\
Colletotrichum & 13.33 & - & 27.78 & 13.33 & - & 10.89 \\
gloeosporioides & 23.33 & 30.77 & - & 40.00 & 40.00 & 26.82 \\
Fusarium semitectum & 13.33 & 46.15 & - & 26.67 & 20.00 & 21.23 \\
$\begin{array}{l}\text { Papulaspora sp. } \\
\text { Pestalotiopsis guepinii }\end{array}$ & 16.67 & - & - & - & - & 3.33 \\
Rhizopus stolonifer & 16.67 & 23.07 & 33.33 & - & 26.67 & 19.94 \\
\hline Represinyyyyyyyyyyyyy
\end{tabular}

- Represents no fungal growth.

Table 1 showed that nine fungal species were isolated from the anthracnose symptom of Himsagar. The mean per cent frequency of Colletotrichum gloeosporioides was the highest (26.82) which was followed by Fusarium semitectum (21.23), Pestalotiopsis guepinii (19.94), A. niger (10.89), A. fumigatus (7.78), A. flavus (4.44), Alternaria alternata (3.33), Papulaspora sp. (3.33) and Rhizopus stolonifer (2.22).

Seven fungal species were isolated from the anthracnose symptom of Langra. The mean per cent frequency of Pestalotiopsis guepinii was the highest (46.83) which was followed by Colletotrichum gloeosporioides (25.33), Alternaria alternata (18.00), A. niger (4.00), A. flavus (2.67), Penicillium sp. (2.00) and Rhizopus stolonifer (1.17) (Table 2).

Six fungal species were isolated from the anthracnose symptom of Amrapali. The highest mean per cent frequency was observed in Colletotrichum gloeosporioides (38.67) which was followed by Pestalotiopsis guepinii (27.33), Fusarium semitectum (12.67), A. niger (12.00), A. fumigatus (5.33) and Papulaspora sp. (4.00) (Table 3). 
Table 2. Per cent frequency of fungi associated with diseased mango variety Lengra.

\begin{tabular}{|c|c|c|c|c|c|c|}
\hline \multirow{2}{*}{$\begin{array}{l}\text { Name of } \\
\text { fungi }\end{array}$} & \multicolumn{6}{|c|}{$\%$ frequency of fungi from different markets (date of isolation) } \\
\hline & Farmgate & Kollayanpur & Pirerbagh & Mirpur-10 & $\begin{array}{l}\text { Kawran } \\
\text { bazaar }\end{array}$ & Mean \\
\hline Alternaria alternata & 20.00 & 50.00 & - & 20.00 & - & 18.00 \\
\hline Aspergillus flavus & - & 6.67 & - & - & 6.67 & 2.67 \\
\hline A. niger & - & - & - & - & 20.00 & 4.00 \\
\hline $\begin{array}{l}\text { Colletotrichum } \\
\text { gloeosporioides }\end{array}$ & 53.33 & - & - & 26.67 & 46.67 & 25.33 \\
\hline Penicillium sp. & - & 3.33 & - & - & 6.67 & 2.00 \\
\hline Pestalotiopsis guepinii & 26.67 & 37.5 & 100 & 50.00 & 20.00 & 46.83 \\
\hline Rhizopus stolonifer & - & 2.50 & - & 3.33 & - & 1.17 \\
\hline
\end{tabular}

Table 3. Per cent frequency of fungi associated with diseased mango variety Amrapali.

\begin{tabular}{lcccccc}
\hline \multirow{2}{*}{$\begin{array}{l}\text { Name of } \\
\text { fungi }\end{array}$} & \multicolumn{5}{c}{ \% frequency of isolated fungi from different markets (date of isolation) } \\
\cline { 2 - 7 } & Pirerbagh & Kollayanpur & $\begin{array}{l}\text { Kawran } \\
\text { bazaar }\end{array}$ & Farmgate & Mirpur-10 & Mean \\
\hline $\begin{array}{l}\text { Aspergillus } \\
\text { fumigatus }\end{array}$ & 13.33 & - & - & 13.33 & - & 5.33 \\
$\begin{array}{l}\text { A. niger } \\
\text { Colletotrichum } \\
\text { gloeosporioides }\end{array}$ & - & 26.67 & - & - & 33.33 & 12.00 \\
$\begin{array}{l}\text { Fusarium semitectum } \\
\begin{array}{l}\text { Papulaspora sp. } \\
\text { Pestalotiopsis guepinii }\end{array}\end{array}$ & - & 53.33 & 60.00 & 40.00 & - & 38.67 \\
\hline
\end{tabular}

Taxonomic descriptions of pathogenic fungi associated with three infected varieties of Mangifera indica.

1. Colletotrichum gloeosporioides (Penz.) Sacc., Fung. Agrum. 2: 6 (1882) (Fig. 1A)

Colony white, sometimes grayish with lighter center. setae absent. Conidia comperatively large, straight, obtuse at the apex, 14.8-24.4 × 3.6-5.2 $\mu \mathrm{m}$. Appressoria abundant, pale to medium brown, circular or slightly irregular.

Specimen examined: Isolated from anthracnose symptom of Mangifera indica, Farmgate, Kollayanpur, Kawran bazaar, Dhaka, F. Islam 5, August 2016. 

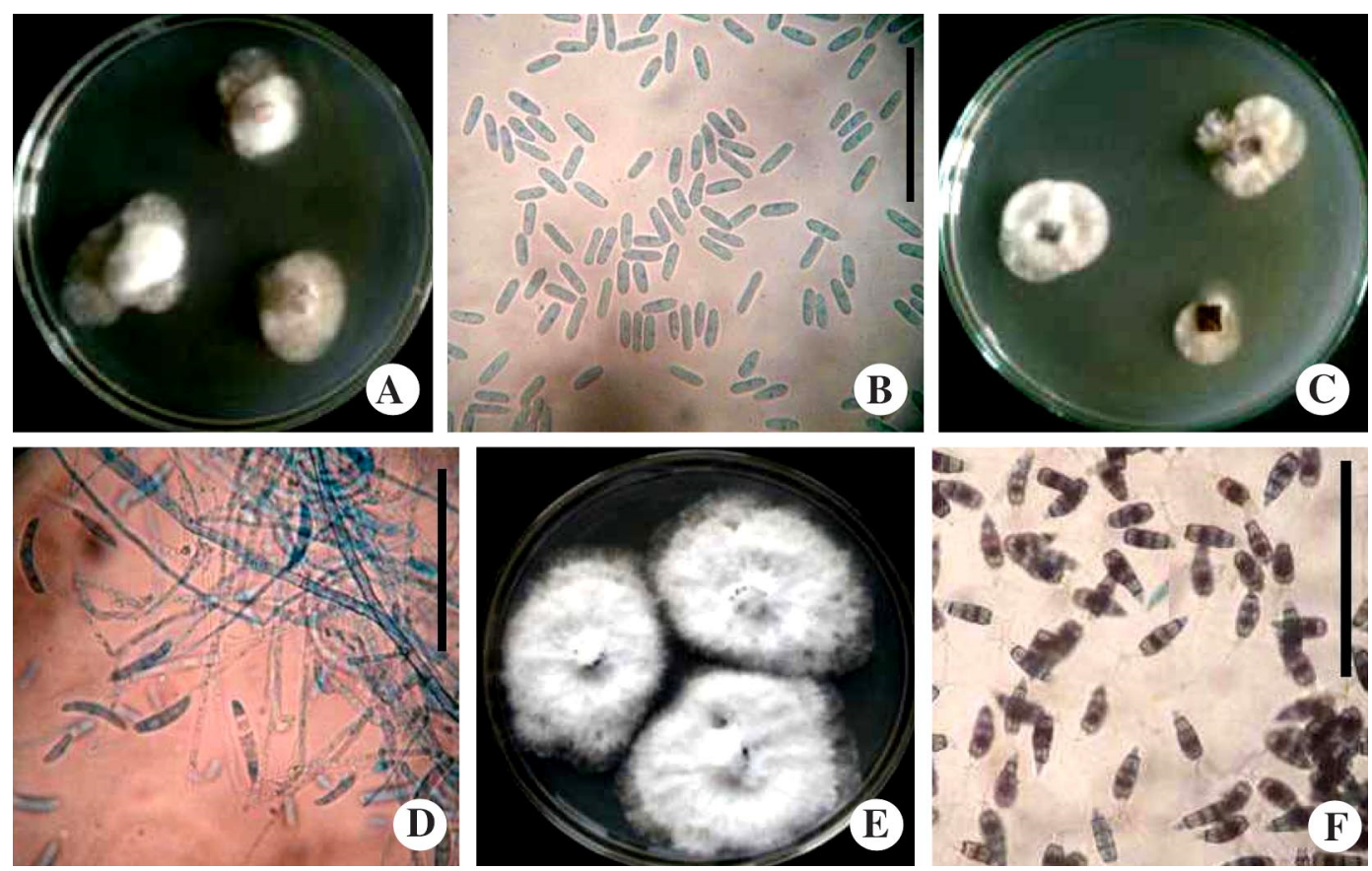

Fig. 1A-F. Colonies and conidia of re-isolated pathogens of Mangifera indica. A-B: Colletotrichum gloeosporioides, C-D: Fusarium semitectum and E-F: Pestalotiopsis guepinii $(\mathrm{Bar}=50 \mu \mathrm{m})$.

2. Fusarium semitectum Berk. \& Rav. In Berkeley, Gravillea 3: 98 (1875)

(Fig. 1B)

Colonies at first white peach tinge and peach coloured from below. Aerial mycelium floccose, peach gradually changing to avellaneous and finally becoming buff brown. Sporodochia absent. Macroconidia formed in aerial mycelium from loosely branched conidiophores. Conidia 3 to 5 septate, curved with a wedge-shaped and pointed apex, 3 septate $17-28 \times 2.5-4 \mu \mathrm{m}$ and 5 septate $22-40 \times 3.7-4 \mu \mathrm{m}$. Microconidia one septate pyriform to obovate, $10-12 \times 2.5-3.5 \mu \mathrm{m}$.

Specimen examined: Isolated from anthracnose symptom of Mangifera indica L., Kollayanpur, Dhaka, F. Islam 6, August 2016.

3. Pestalotiopsis guepinii (Desm.) Stey., Bull. Jard. Bot. État Brux. 19(3): 312 (1949)

(Fig. 1C)

Colonies white, cottony and reverse white. Hyphae septate, branched and hyaline. Acervuli black, small, shining. Conidiophores septate, branched, dark brown, cylindrical or lageniform, formed from the upper cells of the pseudoparenchymata. Conidia fusiform, straight or slightly curved, mostly 3 euseptate: basal cells hyaline, truncate, with an endogenous, cellular, appendage: apical cell conic, hyaline, with 2 or more apica, 
simple or branched, spathulate or espathulate appendages: median cells brown, sometimes versicoloured, thicker-walled, smooth, $14-23 \times 5-7.5 \mu \mathrm{m}$.

Specimen examined: Isolated from anthracnose symptom of Mangifera indica, Farmgate, Kollayanpur bazaar, Dhaka, F. Islam 9, July 2016.

Among the isolated fungi C. gloeosporioides, F. semitectum and P. guepinii were found to be pathogenic to all the tested mango varieties. Control set remains fresh without showing any fungal growth (Fig. 2).
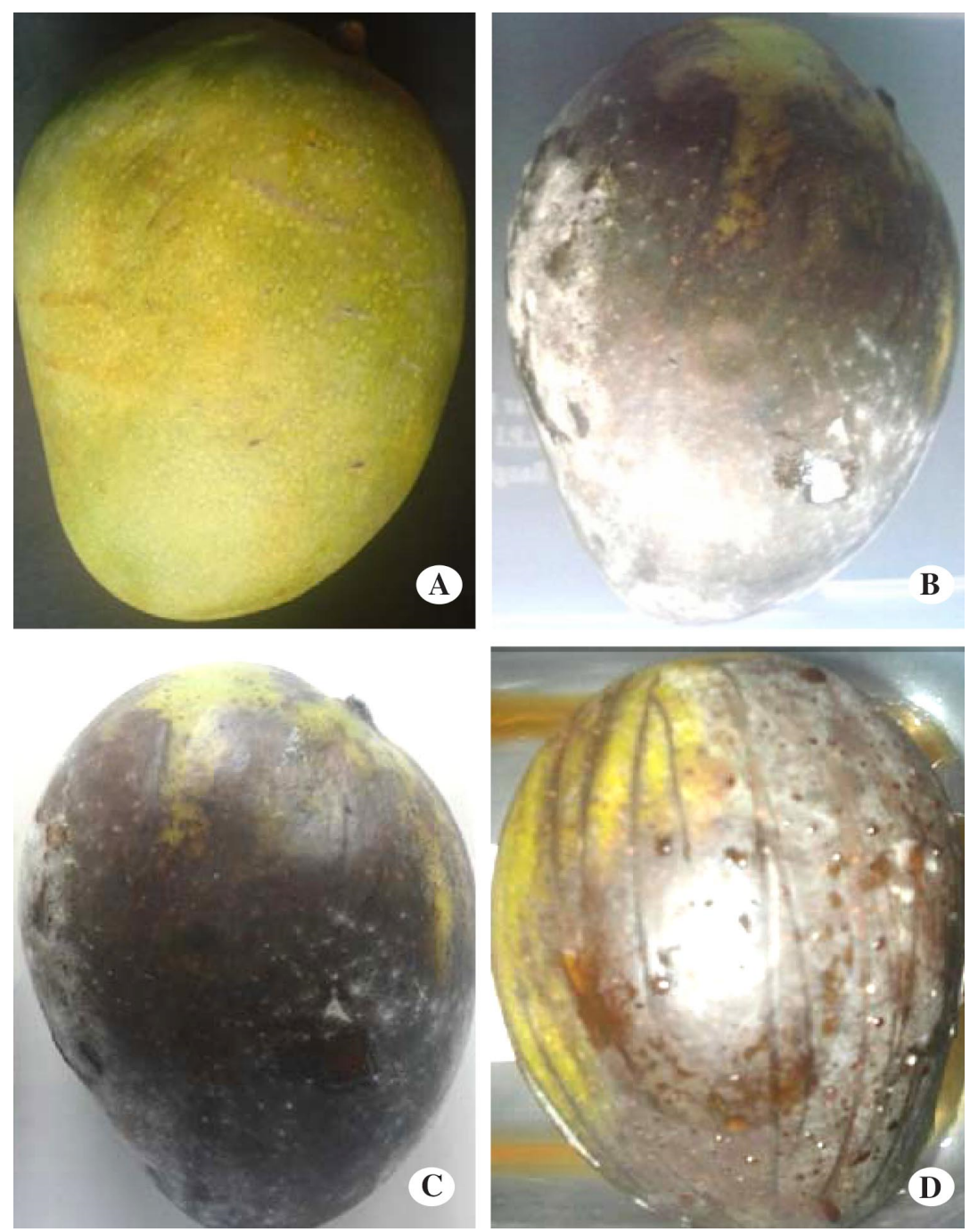

Fig. 2. A-D. Photographs of pathogenicity test in different varieties of mango. A: Control, B: Inoculated fruits with Colletotrichum gloeosporioides, C: Fusarium semitectum and D: Pestalotiopsis guepinii. 
Naznin et al.(16) identified Botryodiplodia theobromae and Colletotrichum gloeosporioides which were isolated from stem-end rot and anthracnose infected mango fruits in Bangladesh. Their identified average fruit infection was 14.30 and $8.9 \%$ for stem-end rot and anthracnose of Langra whereas 14.65 and $8.5 \%$ for stem-end rot and anthracnose of Himsagar mango, respectively. Fungal pathogens involved in mango rotting after harvest include Colletotrichum gloeosporioides responsible for mango anthracnose, Alternaria alternata and A. tenuissima that cause alternaria blight, Botryodiplodia theobromae and Dothiorella spp. responsible for stem-end $\operatorname{rot}^{(17)}$. Maqsood et al. (2014)(18) identified C. gloeosporioides, Lasiodiplodia theobromae, Alternaria alternata, Aspergillus niger and Dothiorella domonicana from Sindhri mango fruits, in which C. gloeosporioides was found the most prevalent in Pakistan. Rajmane and Korekar (2016)(19) reported that Alternaria alternata, Aspergillus flavus, A. fumigatus, A. niger, Botryodiplodia theobromae, C. gloeosporioides, Penicillium chrysogenum and $R$. stolonifer associated with the spoilage of mango fruit in India. Abdullah et al. (2016)(20) found that Alternaria alternata, A. aculeatus, Aspergillus flavus, A. japonicas, A. niger, A. parasiticus, Eurotium amstelodami, Mucor circinelloides, Penicillium viridicatum, Rhizopus arrhizus, Trichoderma koningii, T. harzianum and Verticillium tenerum were associated with post harvest rot disease of mango in Yemen. All the fungi associated with mango as pathogens or saprophytes detoriate fruits qualitatively and quantitatively.

Present results reveal that out of 10 fungal species three were found to be pathogenic to the three varieties of Mangifera indica. The association of Fusarium semitectum, Papulaspora sp. and Pestalotiopsis guepinii with mango is new record in Bangladesh.

\section{References}

1. Abd-Alla MA and WM Haggag 2010. New safe methods for controlling anthracnose disease of mango (Mangifera indica L.) fruits caused by Colletotrichum gloeosporioides (Penz.). J. American Sci. 8(8): 361-367.

2. Awa OC, O Samuel, OO Oworu and O Sosanya 2012. First report of fruit anthracnose in mango caused by Colletotrichum gloeosporioides in south western Nigeria. Internat. J. Scientific \& Tech. Res. 1(4): 30 - 33.

3. Ahmed ZU, ZNT Begum, MA Hassan and M Khondker, SHM Kabir, M Ahmed, AKM Rahman and EU Haque (eds.) 2008. Encyclopedia of Flora and Fauna of Bangladesh. Vol. 6. Angiosperm: Dicotyledons (Acanthaceae-Asteraceae). Asiatic Society of Bangladesh, Dhaka. pp. 408.

4. Lakshmi BKM, PN Reddy and RD Prasad 2011. Cross-infection potential of Colletotrichum gloeosporioides penz. isolates causing anthracnose in subtropical fruit crops. Trop. Agric. Res. 22: 183-193.

5. FAO (Food and Agriculture Organization) 2013. Production Yearbook 2012. Rome, Italy.

6. BBS 2015. Statistical Yearbook of Bangladesh. $2^{\text {th }}$ series, Statistics and Informatics Division, Ministry of Planning, Govt. of the People's Republic of Bangladesh, Dhaka. pp. 200. 
7. FAOSTATE (Food and Agriculture Organization) 2014.

8. Haggag WM 2010. Mango diseases in Egypt. Agric. Biol. J. North Amer. 1: 285-289.

9. Meah MB and AA Khan 1987. Survey of diseases of some important fruit and vegetable crops of Bangladesh. Ann. Prog. Rep. pp. 1-28.

10. Chowdhury MAH and MS Hassan 2013. Hand Book of Agricultural Technology. Bangladesh Agricultural Research Council (BARC). pp. 230.

11. Al-Ameen M, S Shamsi and MA Bashar 2017. Mycoflora associated with infected fruits of different varieties of Musa sapientum L. and their pathogenic potentiality. Dhaka Univ. J. Biol. Sci. 26(1): 101-110.

12. Booth C 1971. The Genus Fusarium. Commonwealth Mycological Institute, Kew, Surrey, England. pp. 237.

13. Ellis MB 1971. Dematiaceous Hyphomycetes. The Commonwealth Mycological Institute, England. pp. 608.

14. Sutton BC 1980. The Coelomycetes. Fungi Imperfecti with Pycnidia, Acervuli and Stromata. Commonwealth Mycological Institute, England. pp. 696.

15. Akter M and S Shamsi 2016. Report on blight of Tagetes spp. caused by Curvularia lunata (Wakker) Boedijn. Bangladesh J. Bot. 45(1): 167-173.

16. Naznin HN, K Nahar, MB Hossain and MM Hossain 2007. Prevalence of important post harvest diseases of mango. J. Agrofor. Environ. 1(2): 25-29.

17. Arauz LF 2000. Mango anthracnose: Economic impact and current options for integrated management. Plant Disease 84: 600-611.

18. Maqsood A, A Rehman, I Ahmad, M Nafees, I Ashraf, R Qureshi, M Jamil, M Rafay and T Hussain 2014. Physiological attributes of fungi associated with stem end rot of mango (Mangifera indica L.) varieties in postharvest fruit losses. Pak. J. Bot. 46(5): 1915-1920.

19. Rajmane SD and SL Korekar 2016. Isolation and identification of fungi associated with spoilage of mango fruit, India. International Journal of Scientific Research 5(8): 2277-8179.

20. Abdullah Q, A Mahmoud and A Al-Harethi 2016. Isolation and identification of fungal postharvest rot of some fruits in Yemen. PSM Microbiology 1(1): 36-44. 